\title{
Personality, coping and atypical facial pain. Case reports
}

\author{
Personalidade, enfrentamento e dor facial atípica. Relato de casos \\ Ludmila Maria Christofolleti ${ }^{1}$, Maria de Fátima Vidotto Oliveira ${ }^{2}$, Silvia Regina Dowgan Tesseroli de Siqueira ${ }^{1,2}$
}

DOI 10.5935/2595-0118.20180016

\section{ABSTRACT}

BACKGROUND AND OBJECTIVES: Idiopathic facial pain is a chronic condition with unknown etiology and pathophysiology. Its diagnostic criteria depend on the exclusion of any somatic cause of orofacial pain. Several studies have investigated anxiety and depression, but there is a lack of publications about personality. The objective of this study was to describe three cases of patients with idiopathic facial pain that had their temperament and character evaluated in order to verify the relation between the findings with pain behavior and pain characteristics. The instruments used were a free interview and the Temperament and Character Inventory.

CASE REPORTS: Case 1 was proactive and had high scores of cooperativity and self-transcendence correspondent to the well-coping behavior. On the other side, cases 2 and 3 showed similarities about their harm avoidance, novelty seeking and poor coping, correspondent to a self-protective insecure personality.

CONCLUSION: These cases show the importance of personality assessment in order to determine coping strategies in complex chronic facial pain such as idiopathic facial pain.

Keywords: Atypical facial pain, Persistent pain, Personality.

\section{RESUMO}

JUSTIFICATIVA E OBJETIVOS: Dor facial idiopática persistente é uma condição crônica cujas etiologia e fisiopatologia permanecem obscuras. Os critérios diagnósticos dependem da exclusão de todas as possíveis causas somáticas de dor orofacial. Vários estudos investigaram frequentes comorbidades psiquiátricas como ansiedade e depressão, mas há carência de estudos que tenham observado aspectos de personalidade nesses doentes. $\mathrm{O}$ objetivo deste estudo foi descrever três casos de pacientes com dor facial idiopática persistente que foram avaliados quanto a traços de personalidade e de caráter, bem como a associação desses traços com as características da dor e o comportamento doloroso. Os instrumentos utilizados foram a entrevista livre e o Inventário de Caráter e Temperamento de Cloninger.

RELATO DOS CASOS: O caso 1 apresentava traços de proatividade e altos índices de cooperatividade e autotranscendência, correspondentes com seu perfil de bom enfrentamento. Por outro lado, os casos 2 e 3 apresentaram similaridades quanto à evitação de dor, busca por novidades e enfrentamento pobre, o que correspondeu a uma personalidade insegura e autoprotetora. CONCLUSÃO: Esses casos mostram a importância de abordar a personalidade do paciente para que estratégias de enfrentamento adequadas sejam estabelecidas para a dor facial crônica complexa. Descritores: Dor facial atípica, Dor persistente, Personalidade.

\section{INTRODUCTION}

Pain is a sensory and emotional experience (International Association for the Study of Pain, 1996) ${ }^{1}$ that after 6 months becomes chronic, losing its biological function and causing permanent or transitory incapacities ${ }^{2}$. Subjective psychic factors play a major role in pain chronification and pain crises, especially when pain is located at the head and / or face, because of the psychic and social importance of this body area. Among orofacial pain diagnosis, atypical facial pain or persistent idiopathic facial pain (PIFP) remains as one of the most complex to evaluate and treat, with the compulsory need of psychological assessment ${ }^{3}$.

PIFP is characterized as diffuse deep and constant chronic pain (International Headache Association, 2013) ${ }^{4}$ that has no etiology behind it and the exclusion of other pathologies is necessary before final diagnosis. It is usually unilateral, located in the maxillary region, described as dull, aching, throbbing or burning 5 . In $50 \%$ of the cases, there are initial physical or emotional traumas and the pathophysiology is associated, at least in part, with deafferentation ${ }^{3}$. Anxiety, depression and pain behaviors are very common in these patients and can be part of the multifactorial
Accepted for publication in January 22, 2018.

Conflict of interests: none - Sponsoring sources: none

Correspondence to:

Avenida Dr. Enéas de Carvalho Aguiar 255 - $5^{\circ}$ andar - Cerqueira César

05403-000 São Paulo, SP, Brasil.

E-mail: silviadowgan@hotmail.com

(c) Sociedade Brasileira para o Estudo da Dor 
aspects involved in pain onset or can be a consequence of chronic pain as a secondary comorbidity ${ }^{5}$. Anxiety can be due to the fear or lack of knowledge of the diagnosis. Despite the wide range of studies investigating emotional issues of chronic pain, there is a lack of studies that evaluated the personality of these patients. The behavior pattern and its motor, psychological, affective and relational reactions are based on the personality that can alter according to the exposure of cultural, social and environmental aspects ${ }^{6}$. Personality is a complex adaptive system directed by internal and external factors that produce the behavior ${ }^{6}$. Thus, even patients with anxiety or depression traits deserve special attention about their personality and character that can influence their coping reaction to chronic conditions such as pain. Personality disorders are associated with low cooperation with treatment $^{7}$. Besides, reward dependence, novelty seeking, and harm avoidance have been associated with the anxiety trait of patients with chronic pain. Moreover, cooperativity and self-transcendence are directly or indirectly associated with coping ${ }^{7-12}$.

The Temperament and Character Inventory (TCI) is an international instrument to evaluate personality, validated to the Portuguese Language ${ }^{13}$. It is considered one of the most complete and trustable tools to evaluate temperament and character in detail, and with an interactive and nonlinear way, with a dimensional assessment ${ }^{14}$. It has also been used in patients with chronic pain $^{8,10,11}$ and thus, it was chosen for this study) ${ }^{13}$.

Identifying and assessing the temperament and character is determinant in the follow-up of patients with chronic pain, and there is a lack of studies in orofacial conditions. Thus, the objective of this case series was to describe the narrative of personality traits of three individuals with PIFP.

\section{CASE REPORTS}

Three patients with PIFP were included. They were under treatment at the Orofacial Pain Clinic of a General Hospital in a multidisciplinary team, and they were diagnosed with PIFP according to the IHS criteria (International Headache Society, 2013) ${ }^{4}$. The local ethics committee approved this project (CAPPesq - HCFMUSP). The patients were informed about the purposes of the research, and all agreed to participate. All signed the informed consent. There was no other pain complaint in these patients, except the face.

A trained researcher that followed the international TCI application guidelines evaluated the patients. It was performed in a silent room, and only the subject and the researcher were present, after the regular appointment of the patient for follow-up and treatment of pain. The patients underwent an interview in order to access psychological characteristics such as anxiety, depression, pain behavior, coping and personality. After, they were also evaluated by Cloninger's TCI ${ }^{14}$, adapted and validated for the Portuguese language ${ }^{13}$. This inventory consists of 240 self-completed 'true' or 'false' questions subdivided into seven personality traits, four temperaments (novelty seeking, harm avoidance, reward dependence, persistence) and three characters (self-directedness, cooperativeness, self-transcendence).

The results were presented by the method of narrative description.
Case 1. Male patient, 58 years old started the treatment at the Orofacial Pain Clinic because of a persistent pain in his face and neck, which was causing difficulties to work. He was a house-builder, and at that moment he was working as a painter. The pain was so intense that he could not paint the ceiling of the houses. Although suffering, he loved his job and did not want to stop. He wanted a painkiller to come back to normal activity. $\mathrm{He}$ was married and lived with his wife. His pain was bilateral and had started 10 years ago. When asked, he described it as throbbing and jumping, with an intensity of 8 on a scale from zero to 10 (visual analog scale). He had been diagnosed with PIFP and was treated with antidepressants, neuroleptics, and anticonvulsant drugs, with partial improvement.

His medical history included poliomyelitis when a child which resulted in a sequela at his left arm. He was a former drug addicted and reported the cure by faith when he started to go to the church. He said he is happy to work as a painter, having many clients and felt bad because he could not keep on working because of the pain. He also had dizziness and was diagnosed with labyrinthitis. Because of it, he was afraid of falling while working. He was very collaborative, communicative and proactive, telling several details. He told that he loved to help other people. In the analysis of the instrument, his profile was according to the findings of a moderate reward dependence and persistence and a high level of cooperativeness and self-transcendence.

Case 2. Female patient, 51 years old with pain on the right side of the face that started 10 years ago. She was a housekeeper and reported intensity of 7 by the visual analogue scale. The pain was very intense, and she said that the sensations were burning and pressing. She told that she lives with the husband and the son and that her work is affected by the pain symptom. However, she needed to keep on working and was avoiding stopping because of the pain. She was discrete, little talking and asked for help to complete the inventory. She also informed that she was frequently insecure and shy, especially when in front of other people, and that she was not used to telling other people (even the close ones) about her feelings or personal problems. Her fear was that they would think her problems are insignificant. After the analysis of the TCI result, she had a high level of harm avoidance and novelty seeking, highlighting a compulsive behavior while shopping. She had very low cooperativeness and self-transcendence.

Case 3. Female patient, 37-year-old was under treatment at the orofacial pain clinic. She was single and lived alone. Her pain was on the right side of the face, and it started 5 years ago. The descriptor was jumping pain, and the intensity was 7 by the visual analogue scale. She reported that the pain was impairing her daily activities, especially work. She was a children's teacher and did not want to talk about her personal life. She was quiet and bored, not interested at all in the evaluation, and she was ashamed to ask about her doubts while completing the inventory. She was completely uncomfortable with the interview. Her results in the TCI were compatible with this description and showed low socialization, discretion, insecurity. She had high harm avoidance and novelty seeking and very low cooperativeness and self-transcendence. 


\section{DISCUSSION}

Psychiatric morbidities are frequent in patients with chronic pain, and the evaluation of anxiety and depression has been extensively discussed in the literature. However, there is a lack of studies that analyzed the role of personality. Fibromyalgia syndrome is associated with high scores of harm avoidance with a tendency to pessimism, insecurity, uncontrollable fear, shame and timidity in the majority of social circumstances besides a chronic sensation of tiredness and fatigue ${ }^{14}$. The cases 2 and 3 are in accordance with the findings of fibromyalgia and other chronic pains ${ }^{7-11}$. They showed shame, timidity, harm avoidance and novelty seeking, aspects that are associated with the anxiety traits in chronic conditions. However, case 1 is the opposite, with a proactive and extroverted personality, having high levels of cooperation and self-transcendence. Part of these aspects may be related to the religious behavior of the patient. In any case, it calls for attention to this type of patient that is also representative and relevant, deserving individual assessment and different coping strategies. Moreover, the self-transcendence can become a coping tool for the other patients represented by cases 2 and 3 . They have an excessive self-centrism, which amplifies the attention to pain, an old-known aspect that triggers pain crises and chronification. Patients in pain can be more focused on details about themselves, and they might have perfectionist personalities. On the other side, self-directedness (not present in this sample) is also another issue associated with self-centrism when there is no self-transcendence ${ }^{14}$.

The case series and the narrative description with a qualitative analysis is crucial when individualized aspects, such as personality, are under investigation. Although the majority of patients have self-centrism, high levels of insecurity, shame, novelty seeking and harm avoidance, we have a lot to learn from the minority. The attention to pain and to themselves can play a role in the chronification and in the triggering of pain crises or treatment resistance. The study of these cases helps in the understanding of coping tools in order to keep the high quality of life and pain management. Besides, in chronic pain, individuals need a deep comprehension of their unique condition.

\section{ACKNOWLEDGMENTS}

All authors participated in the design, discussion, writing and final revision of the manuscript. Dr. Christofoletti evaluated the patients, Dr. Oliveira with Dr. Siqueira analyzed the results.

\section{REFERENCES}

1. Classification of chronic pain. Descriptions of chronic pain syndromes and definitions of pain terms. Prepared by the International Association for the Study of Pain, Subcommittee on Taxonomy. Pain Suppl. 1996;3:S1-226.

2. Watson JC, Sandroni P. Central neuropathic pain syndromes. Mayo Clin Proc. 2016;91(3):372-85.

3. Siqueira SR, Siviero M, Alvarez FK, Teixeira MJ, Siqueira JT. Quantitative sensory testing in trigeminal traumatic neuropathic pain and persistent idiopathic facial pain, Arq Neuropsiquiatr. 2013;71(3):174-9.

4. The International Classification of Headache Disorders. International Headache Society $3^{\text {rd }}$ ed. (beta version). Cephalalgia. 2013;33(9):629-808.

5. Zakrzewska JM. Multi-dimensionality of chronic pain of the oral cavity and face. J Headache Pain. 2013;14:37.

6. Cloninger CR. A unified biosocial theory of personality and its role in the development of anxiety states: a reply to commentaries. Psychiatr Devel. 1988;6(2):83-120.

7. Conrad R, Schilling G, Bausch C, Nadstawek J, Wartenberg HC, Wegener I, et al. Temperament and character personality profiles and personality disorders in chronic pain patients. Pain. 2007;133(1-3):197-209.

8. Boz C, Velioglu S, Ozmenoglu M, Sayar K, Alioglu Z, Yalman B, et al. Temperament and character profiles of patients with tension-type headache and migraine. Psychiatry Clin Neurosci. 2004;58(5):536-43.

9. Knaster P, Estlander AM, Karlsson H, Kaprio J, Kalso E. Temperament traits and chronic pain: the association of harm avoidance and pain-related anxiety. PLoS One. 2012;7(10):e45672.

10. Malmgren-Olsson EB, Bergdahl J. Temperament and character personality dimensions in patients with nonspecific musculoskeletal disorders. Clin J Pain. 2006;22(7):625-31.

11. Nylander PO, Schlette P, Brändström S, Nilsson M, Forsgren T, Forsgren L, et al. Migraine: temperament and character. J Psychiatr Res. 1993;30(5):359-68.

12. Pud D, Eisenberg E, Sprecher E, Rogowski Z, Yarnitsky D. The tridimensional personality theory and pain: harm avoidance and reward dependence traits correlate with pain perception in healthy volunteers. Eur J Pain. 2004;8(1):31-8.

13. Fuentes D, Tavares H, Camargo CH, Gorestein C. Inventário de Temperamento e Caráter de Cloninger - validação para a versão em português. In: Andrade LH, Zuardi AW, Gorenstein C. (Eds), Escalas de Avaliação Clínica em Psiquiatria e Psicofarmacologia. Săo Paulo: Lemos Editorial; 2000.

14. Cloninger CR, Svrakic DM, Przybeck TR. A psychobiological model of temperament and character. Arch Gen Psychiatry. 1993;50(12):975-90. 